\title{
電子·電気材料特集 II
}

\section{耐熱性電気絶縁材料の機器への応用}

吉岡浩

1.はじめに

電気・電子機器 (以下機器) 命化，高信頼性化は必然的にそれに使用される電気絶縁 材料(以下絶緣材料)に対して上り㦑しい特性を要求する ようになった。特に，運轱温度の上算に伴って酎熱性の 向上が不可欠になり，てれに対応するため新しい耐熱性 高分子を用いた各種の酎熱性䋓縁材料が次々之開発され， 実用化されてきた。絶縁材料の耐熱性の良否は直接機器 の陦命や信頼性に影響するので，これらの優秀な耐熱性 絶縁材料の出現が今日の機器の著しい進歩，発達をもた らした大きな要因の一つ之言っても差し支えないである う。一方, 宇宙開発, 海洋開発, 新エネルギー開発その 他の新技術開発に関連して従来にない苛酷な環境で幾器 が使用されることが多くなるが，乙れに対しても耐熱性 絶縁材料が大きな役割在果たしつつある。

また，我々の日常生活に密接な関係を有する家電機器 几もその安全性を確保するた的熱性絶緑材料加いろい ろ上取り入れられており，電気用品に使用する絶縁物の 使用温度の上限值の設定は絶緑材料の耐熱性に对する大 方の諗識を新たなものにしている。

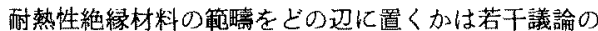
余地はあるが，現状では $155^{\circ} \mathrm{C}$ (F種)乃至 $180^{\circ} \mathrm{C}$ (H種) あるいは $180^{\circ} \mathrm{C}$ 以上(C種)の高温で長時間連続運転に酎 える機器の絶緣構成に使用できる絶縁材料之考えてよい であろう。な⿺，連続使用の時間は 2 万時間あるいは 4 万 時間が基準とされることが多い。

絶縁材料はその種類や形態がきわ的て多種多様で，し 加わ大抵の場合用途に応してて2 種類以上を組合わ甘て秝 縁組織 として機器に適用される。従って，個々の耐熱性 絶縁材料の機器に対する応用状況を明磪に説明するてと

The Application of Heat Resistant Insulating Materials for Electric/Electronic Apparatuses HIROSHI YOSHIOKA

Nuclear Energy Group, Applied Metallurgy and Chemist Department, Toshiba Corporation 東芝原子力材料化学技術部
はなかな加難しい。そこで、いくつかの分野の機器につ いてその概要を御紹介させて頂くとととする。

\section{2. 耐熱性絶縁材料の所要特性}

絶縁材料の耐熱性は耐熱軟化性，耐熱衙撃性の上うな 短時間高温にさらされた場合の物理的変化に起因する耐 熱性上耐熱劣化性の上うに化学的変化にもとつく経時的 耐熱性とに分れるが，後者が特に重要視される。

この耐熱出化性の良否加酎熱性絶縁材料の性能を決定 する最大のポイントになるが，絶縁材料としての機能在 十分に発揮するためにはとの他幾多の特性が要求される。

（1）耐熱劣化性（熱安定性）がすぐれていること

高分子材料を長時間高温で加熱すると側銷や主鎖の切 断，分解が起って厚さや重量が減少し，絶縁耐力や機械 强度が低下し，絶縁破罗をもたらす。一般に機器が使用 される空気中では熱酸化少化によっててれが促准され， また，高温になる程この煩向が著しいので，耐熱出化性 のすぐれた絶縁材料の開発が現在なお重要な研究課題の 一つとなっている。

（2）熱軟化，熱変形を起しにくいこと

熱軟化や熱変形に上る絶縁材料の溶出や変形は絶縁耐 力の低下を招き，絶縁組織の性能を損うのでガラス転移 点，軟化点，融点加高く 熱変形温度の高いととが要求 される。ガラス䋐維強化や冭填剤配合に上って熱変形温 度は相当程度上昇させるととができる。

(3) 耐熱街慗性に富むこと

電気機器の運転一停止の絽り返しあるいは昼夜の温度 差などによって絶縁組織加加熱一冷却サイクリング效果 を受けきれつを生ずるとしがある。殊に、絶縁層の厚い 注形材料ではこの傾向が著しいので，低起張，低収縮偫 脂や可上う性㥘脂の利用，可上う性付与剂や充填風の配 合加必要になる。

（4）難燃性，不㜣性を有すること

機器の安全性の点加ら絶縁材料の難燃化は韭常に重要 で，少なくとも自己消火性であることが要求される。

一般に，耐熱性のすぐれた絶縁材料は熱分解を起し難 いため耐燃性の良好な6のが多い。特性の低下や腐食性 
を伴わない難燃化手法の開発が望まれる。

\section{（5）電気特性の良好なこ之}

絶縁材料本来の目的加方当然綿縁抵抗，絶縁破壊電玉， 誘電特性などの基本的電気特性がすぐれ，加つ，とれを 高温まで保持することが要求される。また，耐ア一ク性， 耐コロナ性，耐トラッキング性などの環境的電気特性(耐 放電出化性)す良好でなくてはならない。

絶縁抵沉之絶縁破壊電生は高分子を利用した絶緣材料 では殆どが一定水準以上の值を有しており，一方，誘電 特性は分子構造に依存するところが大きい。乙れ対し て耐放電劣化性は高分子の弱点の一つで，現用の稞熱性 絶縁材料はこの点はまだ非常に不満足と言えよう。

この改良には水和アルミナなどの無機窗充填剂の配合 やマイカとの組合わせが行なわれている。

(6) 成形性, 加工性の良いこと

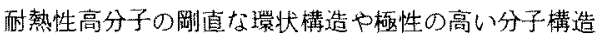
に基つく高融点，高軟化点や不溶性加成形，加工心面て は逆に尔点となるととが多い。即方，シリコーン臌脂， ポリイミド，ポリテトラフロロエチレンなどにみられる ように硬化温度加高加ったり，成形性化少ったりする。

最近では機器のコストダゥンや生産性向上の見地から 成形性の良い，加工性(切削，切断，呀孔など)のすぐれ た耐熱性絶縁材料が強く要望される上うになって扔り， 上記の材料も他の高分子とのブレンドや化学的変性に上 って成形性，加工性の改善加話られている。

(7) 適合性

絶縁材料は殆どの場合数種類が組合わされて絶縁組織 として使用される。それ故，組合わせ方によっては相蛥 作用で熱出化が促進されることもあるので束用段階では 材料間の適合性を十分に秤価することが必要である。

\section{3. 耐熱性絶縁材料の䎂要}

耐熱性絶縁材料の範疇をF種以上と考えると古く加ら 使用されてきたシリコーン樹脂をはじめ，ふっ素樹脂。 ポリイミドを代表とする芳香族・複素環酎熱樹脂および ポリスルホンなどー連の落香族酎熱性熱可塑性樹脂があ げられる。とれらの樹脂はそれぞれ多種多様の製品が開 発さ机，市服されて求り，耐熱性絶縁材料として多方面 の用涂に重用され，成果をあげている。

\section{(1) ふっ素樹脂}

ポリテトラフロロエチレン(PTFE)を主体とする各理

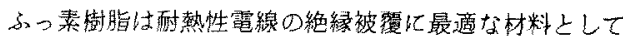
重用されており，すぐれた誘電特性を活用して高周波ヶ ーブル，同軸ケーブル コンピュータ用フラットケーブ ルの絶縁にあ利用される。ポリエチレンーテトラフロロ エチレン(ETFE)，ポリエチンークロロトリフロロエ
チレン(ECTFE)などの開発によって成形性が改善され， 絶縁部品ししての用途も広加りつつある。

\section{（2）芳香族・裉素環而熱樹脂}

ポリイミド樹脂を中心としたとの系統の酎熱樹脂は既 に機器のH種絶縁構成に必要不可欠な材料之なっており， 特に，ポリイミドフィルム(カプトン)、ポリイミドワニ スお汥芳香族ポリアミド(アラミッド紙，ノーメック ス）は著しい発展をみせている。また，ポリイミドエス テルとポリアミドイミドは耐熱性エナメル線ワニスとし て利用洒値が大きく，使用量も漸增しつつする。

その他，ポリビスマレイミド(キネル・ケルイミド)格 リビスマレイミドートリアシン樹脂(BT樹脂)は成形性， 加工性のすぐれた新しい甪熱性樹脂として成形材料，注 形材料，皘層品などの形態で絶縁材料の分野に於いても 今後の発展力゙期待される。

\section{（3）耐熱性熱可塑性樹脂}

ポリスルホン(PS), ポリエーテルスルホン(PES), ポリフェニレンサルファイド(PPS), ポリエーテルエ ーテルケトン(PEEK)、ポリアリレート(Uポリマ)など の比較的新しい熱可塑性の耐熱性樹脂はポりイミドに比 ベて和熱劣化性の点では一特劣るが，その县秀な成形性 と扣工性孛利して酎熱性の絶縁部品や機構部品，プリン ト回路基板，頑熱性フィルムなどとして次第に実用化の 方向に進九でいる。縮合型の雱熱性樹脂に兒られない高 度の耐湿熱性，酎熱水性を有することも大きな特徽で， 酎放訝線性屯良好上言われる。

\section{（4）耐熱性薄菒絶緑材料}

絶縁材料の主要分野を占める薄葉絶縁材料(フィルム， シート，紙，合成紙，不織布，ワニスクロス，テープ, チューブなど)の中，耐熱性フィルムとしては上記の+゚ リイミドが大半を占めているがその他，ポリヒダントイ ン、ポリパラバン酸(PPA)，ポリアミドイミド、ポリ オキサジアゾール(POD)，全芳香族ポリアミド䒺( $\mathrm{A}$ フ イルム)など多種類が開発されている。

フィルム上不織布，紙，ガラスクロス，マイカなどを 貼合わ甘た絶縁材料は電気特性乞機械强度をそれぞれの 材料加分担し，単一材料よりもすぐれた特性を与える。 無機材料上の貼合わせは耐熱性の问上に効果的である。 貼合わせ材料は回転機のスロットライナ，段間あるい は畨間絶縁材料，ウエッジ材，变在器の相間絶縁材料， コイルエンドの博強材などとして用途が広い。

代表的な香のよしてか゚リエステルフィルムーアラミッ ド紙があるが，熱劣化における電気特性の低下を前者が 機械強度の低下を後者が防ぎ，輎熱性薄葉䋓縁材料とし て偉力を発揮する。カプトンフィルムの片面または雨面 にテトラフルオロエチレンーパーフルオロアルキルビニ 
ルエーテル共重合体(テフロンPFA)をコーティングし て接着性を付与した耐熱性複合フィルム手製造されてい る。 200 ～ $260^{\circ} \mathrm{C}$ 程度の耐熱性有する。

\section{(5) 強化プラスチック}

ガラス綫維やガラスクロスを耐熱性樹脂亡組合わせた 强化プラスチックは寸法精度上熱变形温度が高く，耐熱 性絶緣材料としての利用価值も大きい。ガラス纎維強化 (GFRP)が大部分であるが，ボロン䄉維強化(BFRP)， カーボン瀻維强化(CFRP)，ケブラー強化(KFRP)，炭 化けい素織維強化 (SFRP)，アルミナ繊維強化 (AFRP) などのより高強度の強化プラスチックも開発が進められ ており，酎熱性の絶縁板，絶縁棒，絶縁部品などへの利 用が期待できる。

ガラス強化の他アルミナ，シリカ，タルク，マイカな よ゙の無機充填剂の配合によっても㴻脂の熱変形温度は上 昇する。しかし，耐熱劣化性は充填剤の添加で逆に促進 される場合もある。殊に，充填剂中に銅、鉛などの鋝属 あるいはその塩化物や酸化物が存在すると熱书化が著し く促進されるので注意要する。

\section{4. 重電機器への店用}

重電関係の機器では使用期間の㡲いとともあってちく から絶縁組織の耐熱寿命が非常に葷要視されてきており， 数多くの酎熱性評価試験が行なわれ，データの蓄皘も多 い。最近ではマイカ，ガラスクロスなどの無機絶縁材料 に代って，ポリイミド，アラミッド紙など酎熱性有機絶 縁材料の進出が目ざましいもの加ある。

\section{(1) 回転機への応用}

（1）低王汎用モータ：この種のも一多は使用条件の多

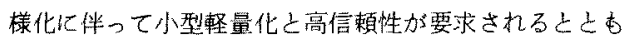
に沉用機種の宿命として常にコストダウンへの努力加要 望される。とれらの要求をバランス上くみたしながらそ の絶緣組織はA種 $\left(105^{\circ} \mathrm{C}\right)$ 加ら $\mathrm{E}$ 種 $\left(120^{\circ} \mathrm{C}\right)$ ，更にB種 $\left(130^{\circ} \mathrm{C}\right)$ 加ら F種 $\left(155^{\circ} \mathrm{C}\right)$ 一之順次耐熱性の向上が住加

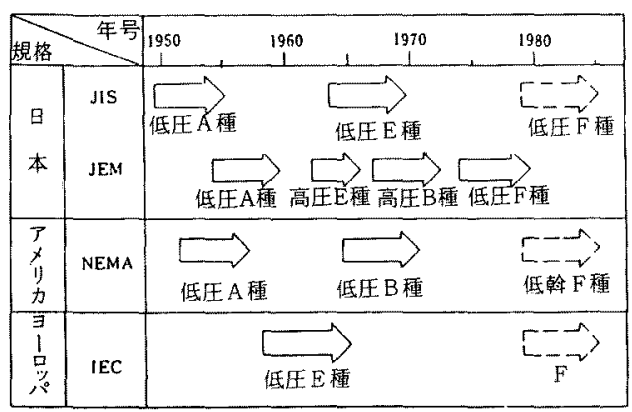

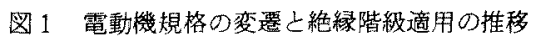

られてきている。コイル卷きに使溯されるエナメル線仗 ホルマール線や捍エステル線加らポリイミドエステル 線やポリアミドイミド線など高洒ではあるが酎熱性のすぐ れたものへし移りつつあり，乙れと併用するコイル含浸 ワニスにあ耐熱性の良いポリエステルイミドワ二スやポ

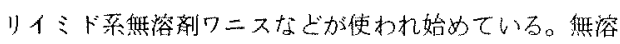
剂ワニスの場合は滴下含浸処理によりモータの生虐性向 上が可能になる。なお，エナメル線上含浸ワニスの組み

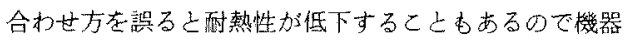
に応用する場合は矛舟者の適応性について十分な検討 を行なうことが必要とされている。

ポリイミド粉体整料は $200 \mathrm{C}$ 程度の高温に於ても電受 特性，機械強度，接着力が良好なため小型モ一夕の鉄心 絶縁，わたり導体の絶緑，各種コイルの対地絶縁，耐熱 性接着剂などとして䈏要增加期待できる。

てれ迄名よ゙ポリエステルフィルムで占められていたも ータのスロット絶縁や屡間絶縁の材料化がリイドフ ィルムやアラミッド紙が一部で応用されるようになり上 記の酎熱性エナメル線や含浸ワニスと併せても一タ絶縁 組織の耐熱寿命乞信頼性を格段に河上させている。

(ii）中，小型電陻機：数十乃至数干 $\mathrm{kW} ， 3$ 乃至 13 $\mathrm{kV}$ 級の謤導電動機や同期電動機などでは機器容量の增 大，小型軽量化，運転効率の向上，高信頼化执よび保守 の簡易化などの見地加らやはり的熱䋓緑組織が採用され るようになっている。特に、コイル絶縁では耐熱エポキ シ樹脂ワニスやポリイミド栾無潈郕ワニスを用いた真空 含浸方式あるいは，無溶剤ポリイミド樹脂などを含浸し て半硬化状態(せミキュアー)にしたマイカテープをコイ 儿導体に巻き付け加熱硬化させて耐熱性絶縁層を形成 させるレジンリッチプリプレグ式などが盛んに行なわ れる。高压霓動機の絶縁テープには耐コロナ性のすぐれ たマイカが重用されているが，その裹打ち材ししてポリ
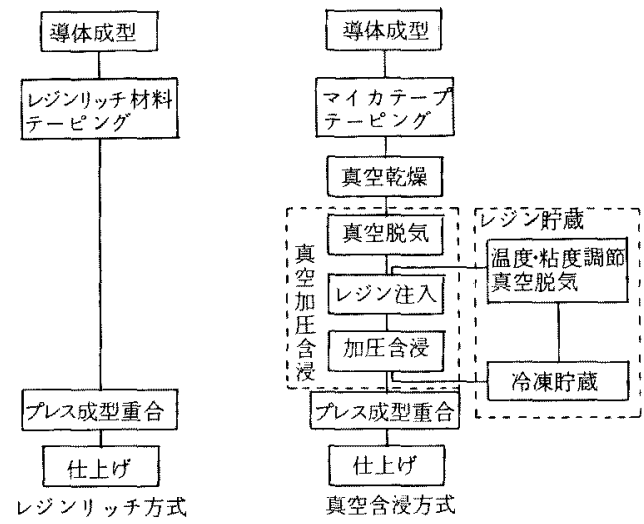

図2 レシンリッチ方式上真空含浸方式の製造工程 


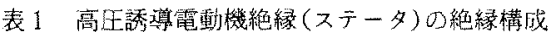

\begin{tabular}{|c|c|c|c|c|}
\hline 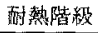 & 電 & 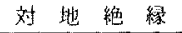 & 含漫ワニス & 処理方式 \\
\hline B 稞 & $\begin{array}{l}\mathrm{OB}-\mathrm{DGC} \\
\mathrm{OB} \text { 㰌 } \\
\end{array}$ & $\begin{array}{l}\text { ○レークフイカ } \\
\text { ○杽成マイカ }\end{array}$ & $\begin{array}{l}\text { ○アルキット } \\
\text { ○ポリエステ }\end{array}$ & \multirow{3}{*}{ 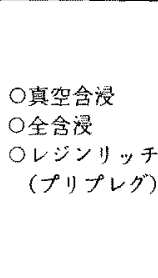 } \\
\hline 藕 & 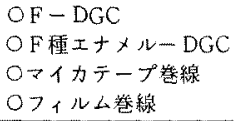 & $\begin{array}{l}\text { ○レークフイカ } \\
\text { O耧成マイカ }\end{array}$ & $\begin{array}{l}\text { Oエポキシ } \\
\text { Oアルキット }\end{array}$ & \\
\hline $\mathrm{H}$ 槿 & $\begin{array}{l}\mathrm{OH}-\mathrm{DGC} \\
\text { OH種フィルム巻線 }\end{array}$ & $\begin{array}{l}\text { ○フレークマイカ } \\
\text { O策成マイカ }\end{array}$ & $\begin{array}{l}\text { Oシリコーン } \\
\text { Oポリ1 } \\
010\end{array}$ & \\
\hline
\end{tabular}

コイルの含漫処理にはシリ コーンワニス, ポリイミドワ 一ス,ポリジフェニルエーテ ルワニスなどが使用されるが， 更に，固定子コイルをエポキ シ澍能の代りに無溶剂ポリイ ミド樹脂でミールドするとと に上って完全H種の高混用電 勤機か得られる。

この他，回転機関係で古
エステルフィルムや同不織有の代りに酎熱性の良いポリ

アミドィドフィルムやポリパラバン酸フィルムなよ゙の 利用屯考えられる。

(iii) 恖流㙨，産業用直流機：車轌用直流機しもF㮔絶 縁が主流であるが種絶縁古採用されている。

新幹線，新々幹線用なよ゙で代衰される車輀モ一夕は取 付け寸法加制限され，小型僌量化が強く要求される。ま た，高速化や笔引力增大のため出力を上げねばならず，

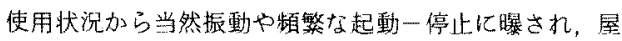
外走行による環境劣化の問題もある。これらの蹱害に打 ち克ってもータの機能を十分に発揮するために惊高性能 の耐熱絶縁組織の採用加必須になってくる。例えば，H 種車䊖モータのコイル卷線にはがリイミド線，ポリアミ ドイミド線，ポリイミドテーピング線，ポリアミドイミ ドテーピング線なよ゙が，スロット紿緣，曾間絶緣用のフ ィルムやテープにはPTFEフィルム，ポリイミドフィル ム、ポリアミドイミドフィルム、アラミッド紙などが用 いられる。亘流機はコロナの影響が少ないので醀熱性プ ラスチックフィルムの活踓の場加大き固定子の主絶縁 にマイカに代えてポリイミドフィルムを使用すると絶縁 層の厚さを半分にするとしができるので，占皘率が小さ くなり，命却効果す向上して容量の增㧑が副机る。

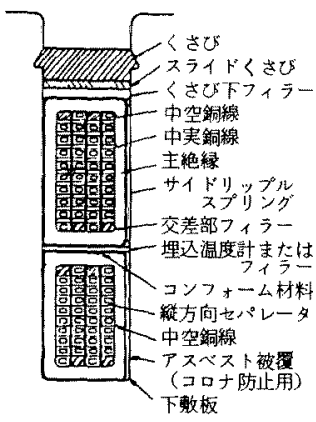

(a) 水令那固定子コイル 断面

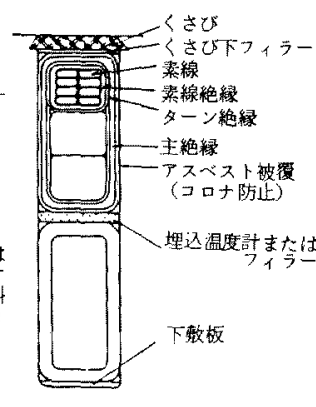

(b) 固定子コイル断面の 一例(多回巻 コイル)
図 3 固定子コイル断面图
速回軽，高負荷モータの整流子絶縁材料之してポリアミ イビスマレイミド樹脂が好適と言われる。フェノール樹 脂上同様成形加工性に富み区縮成形，トランスファ成形， 射出成形，押出成形が可能で，成形品は寸法安定性之機 械的强度が大きく，200 250 C で常時使用に积える。 耐熱衝整性も良い。

アラミッド紙は高压電動機や発電機の尊体絶縁，コイ ル絶縁，スロットライナ，Uリング，半硬化プリプレグ テープ基材などとして広く応用されており，耐熱性に富 んだ薄い絶縁層を形成することによって機器の熱放散を 容易にし，機器の小型僌量化に大きく寄与している。

耐熱エナメル線関係でば一般にH種の機器にはポリイ ミド線，ポリイミダゾピロロン線，ボリアミドイミド線 などが，F種の機器には主としてポリイミドエステル線 が使用されている。ポリエスデルの上にポリイミドエス テル、ポリアミドイミド，ポリイミドなどを二重に熱布 したダブルコート線は酎熱性が良好でかつ，経消的でも あるため，䧿熱椧湅機器なしに霍要加增えつつある。

コイルのワニス含浸処理在省くため自己融著エナメル 線が一部で利用されている。フェノキシ系，ポリスルホ ン系、ポリイミド柔など数㮔類の製品があるが，融着温 度が高く，固着力，篦膜特性にまだ不十分な点があり， 更に，高性能の新製品の開発が待九れる。

\section{(2) 静止器への度用}

油絶縁变王器では熱の放散が良好で運転温复の上昇も 少ないが, 乾式変㗊あるいはレジンモールド変王器で は熱伝導汃悪くなるため絶縁組織の耐熱性向上が求めら れ耐熱性絶緣材料もある程度利用されている。

油絶縁変死器であシリコーン油絶縁変圧器には油浸ア ラミッド紙やその成形品が絶縁構成に応用される。

(1) 乾式変压器: 六ふっ化硫黄 $\left(\mathrm{SF}_{6}\right)$ ガ又絶縁変压器 やH㮔乾式絶縁変田器で约層間絶縁, バリア絶縁, リ一 ドおよびタップ絶縁などにアラミッド緍を，また，絶縁 筒，絶緣棒には耐熱性の良いGFRPを使用する。

(ii) レジンモールド変圧器: 機器の設置面䅢の縮少, 火苂事故防止，安全確保，低騥音化などの見地加ら高層 


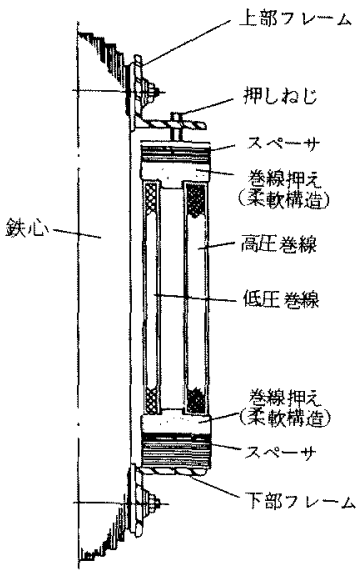

図4モールド变压器の巻線支持

ビル用を始め屋内用変珐器にはエポキシ惜脂でコイル全 体老注形したレジンモールドタイブが多くなっている。

乙の機喠も縮少化，高電生，大容量化伴って運転温 度の上昇が澼りられなくなっており，現在のエポキシ樹 脂上り耐熱分化性と利熱衝撃性のすぐれた，作業性の良 い注形樹脂が要望され石状況にある。エポキシ樹脂の附 熱性の向上をは加たあのとしてはエポキシ/ィソシア ホート樹脂(MIレジン)、エポキシ/BTレジンなどが あるが実機への応用に必要なデータがまだ得られていな い。ポリイミド系無溶剂ワ二ス仕熱变形温度加高く，酎 熱少化性6大きいが，その反面硬化収縮が大きく，脆く て密着性に之しい欠点老有するので改良が望まれる。

巻線の罥間絶縁にはアラミッド紙が用いられるが大型 のモールド変圧器ではカプトンなどを使って熱念力に上 る垔在小さくするととす行なわれる。絶縁筒，絶縁棒に は䞑熱性のGFRPが使用されている。

(3) コンデンサフィルム

高温用コンデンサの誘電体ししてポリスルホン，カプ トンなどの耐熱性フィルムが芯用され始めた。

\section{5. 家電機器への応用}

テレビ，冷蔵庫、洗濯機、ルームエアコン，電子レン ジ，電動工具など日常各家庭に見られる家電機器に使用 されるプラスチックの約80名は構造柎料(主亡してハウ ジング・カバー類)で，乙れむ電気絶縁性を必要上すると てろから広い意味で絶縁材料上言える。ての他，コイル ボビン，ブラグ、ソケット、コネクタなどの絶縁部品、 器内配線用電線などにも種々の絶縁材料が使用されてい る。一般に，家電機器は湿度上昇が小さく，また，使用 材料に対するコストパーフォマンスの笽しい機種が多い
ためむあってこれまで耐熱性絶縁材料の使用範用は限定 されており，使用量屯少なかった。

しかしながら，この分野でも機器の安全性と信頼性の 点加ら，成形性，加工性にすぐれ，而燃性の良い积熱性 絶縁村料加次第に取り入れられてゆくものと思打れる。 次に使用状洗の一端を述べる。

\section{(1) 電子レンジ}

使用目的上高温にさらされる機会が多いので内部には 高温で電気絶縁性の良い酎熱部品が用いられている。そ れらの部品は従来ふっ䒺樹脂とシリコーン樹脂が主体を 占めていたが，次第に成形性の良いPPSなどの耐熱性 熱可塑性樹脂に移行する倾向にある。一例をあげると， パネルにガラス強化ポリエチレンテレフタレート，スタ ーラシャフトやローラにふっ㨞樹脂あるいはポリフェニ レンオキサイド(PPO，ノリル)，パッキング材にシリ コーンゴムなどが使用されている。

駆動ギヤ，回転ギヤ，伝達シャフトにはPPSが応用 されるようになり，家電機器の中では耐熱絶縁材料の多 い部類伅淈する。

\section{(2) 電熱器具}

電気ストーブ, 電気炬蛙, ホットプレート。天火、ア イロン，温水器などの発熱体周辺の絶縁材料には特別に 宮度の耐熱性が要求される。現状ではマイカ，ガラスク ロスなどの無機絶縁材料かての大役を果たしている。

\section{(3) 電動工具}

過負荷のかかるこしが多いのでH㮔絶縁のモー夕が装 備される。卷線にはポリイミド線，ポリアミドイミド線 が使用され苛酷祍運転に十你耐えられるよう設計されて いる。ハンドルやハウジングには軽量なガラス繊維強化 ABS 樹脂やポリカーボネートなどが用いられる。

\section{（4） テレビ受像機，VTR}

ポリアセタール，ポリブチレンテレフタレート，リ ルなよ゙のエンジニアリングプラスチックが主体で，耐熱 性絶縁材料の使用䇢所はあまり見受けられない。

（5）音䅉機器(ステレオ，レコートプレーヤ)

機構部品, 絶縁部品にはポリア七タール，ノリルなど が使用されているが端子板やコイルボビンには寸法安定 性の大きなポリスルホンなども採用される。

(6) ルームエアコン

最近人気を集めているオールシーズンタイプのルーム エアコンでは補助七ータの輻射熱などで 100 C近くまで 昇温することもあるのでファン数には酎熱性，耐燃性の 良好なガラス瀻維強化プラスチックが使用される。

一般に，家電機器はハウジングや部品のプラスチック 化によって軽量化されるとともに，低綮音化，低振動化 が計られ，防錆にあ竒与する。製造工程の削減もでるる 
ので今後各方面に低コストの酎熱性熱可塑性樹脂の利用 が期待される。また，冷涷機用コンプレッサモータの巻 線には酎熱性と酎冷媒性怔要求されるところからポリエ ステルイミド線，ポリアミドイミド線などの耐熱性エナ メル線が使用さ扎る上うになった。

(7) ヘアスタィラ

$200^{\circ} \mathrm{C}$ 程度の高温でも㧧鞄で在ず，また，絶縁性の低 下が少ない材料としてPESが応用される。

\section{6. 電子機器への応用}

コンピュータ、半導体をはじめとするエレクトロニッ クスの発展は周知の如く実に目賞しいものがあるが，と の分野でも回鉻基板，封圤㴛脂，電子部品用材料，電線 被覆などとして耐熱性絶縁材料が応用されつつある。

(1) コンピュータ

コンピュータ用回路基板にはガラス強化エポキシ臌脂 よガラス強化ポリイミドが，末た，高周波特性が要求さ れる場合にはPTFEが主に用いられる。

大型コンピュータの多畨配線基板にはガラス强化格り ビスマレイミドなども利用され始めたようである。

ETFEはPTFEよりも軽く，機械強度や耐力ットス ルー性も大きいためコンピュータ配線の絶縁被㠅に利用 されるようになった。ジャック、コネクタ、スペーサな よ゙絶縁部品にはガラス強化ポリカーボネート，ガラス強 化ジアリルフタレート澍脂などが使用されている。

\section{（2）印刷配楾基板}

エレクトロニックス用にはエポキシ樹脂ーガラス䅪層 板が主力を占めてきたが寒装密度が增し，多層化，高菓 皘化がすすすにつれて耐熱性のすくれたシリコーンーガ ラス，ポリイミドーガラス皘層板がー部で実用化され始 めた。殊に，ポリイミド采の高密度多層配線用銅張棈㲊 板は熱膨張加小さく 高混で寸法安定性に富み，情報观 理用コンピェータによって不可欠な構造䋓縁材料亡なっ ている。成形サイクルが長く，作業性化少るなよ゙の欠点 は濑次改良されつつあり，ス儿ホール信頼性の高い高密 度多層基板用の新しいポリイミドむ開発されている。

酎熱性印刷配線基板にはこの他トリアジン樹脂ーガラ ス、フェノールアラルキル樹脂(ザイロック)一ガラスな どああり，いずれも $600^{\circ} \mathrm{C}$ 程度のハンダ耐熱性を示し， $300 \mathrm{C}$ 亿 30 分程度暴して屯特性の変化がなく，工ポキシ 樹脂一ガラス基板化匹敵する機械強度を有する。

\section{（3）フレキシブル印刷回路基板}

柔軟性に要み，自由に立体配鼣ができるのが大さな特 徴である。軽量で，配線に要する特間が短く，㙨器の信 頼性向上に役立つ。現在ポリエステルフィルムが基材と して広く利用されているが酎熱性を要する場合にぱポリ
イミド, PTFE，FEPフィルムやアラミッド紙，ガう スクロスーエポキシ樹脂などが用いられる。ポリイミド ブィルムは高伍で，耐湿熱性に難点はあるが，耐熱性に 富み，難燃性で機械強度も大きいため計測機器，カメラ， 時部，コンピュータ、電卓，オーディオ製品，ファクシ ミリ，トランシーバ，自動車のダッシュボードなどの多 層配線基材しして重用される。最近ではフロッピーデス ク、プリンタヘッドケーブルなどの駆動部にも採用され て求り，年間 40～50名の急成長老みせている。

耐エッチング性，耐メッキ性の改善が課題である。

各種の基材フィルムと適合性の良い耐熱性接着剂の開 無も待たれる。

\section{（4）封止樹脂}

現在半導体やIC の封止樹脂の殆じがエポキシ樹脂で 占められて和り，耐熱性要するパワートランジスタや 高密度実装素子に対して唠かにエポキシーシリコーン臌 脂やシリコーン樹脂が使用される状況にある。しかし， 今後素子の微細化につれて封止樹脂にも酎熱性が強く要 求される屯の上思われポリイミド系封止樹脂の開発ある いはPPSの利用などあ考えられている。プラスチック パッケージがますます小型化、薄形化する一方，封止樹 脂に対寸るハンダ政熱性，耐クラック性，耐湿熱性など はより䞄しく求められるようになるととは明ら加で，近 い将来現用のエポキシ街脂の特性の限界をこえることも 予想される。乙れに対応するためにはシリコーンーポリ イミドやラダー型シリコーン樹脂のような新規の高性能 耐熱性封止樹脂の開発もすすめ如ばならないであるう。

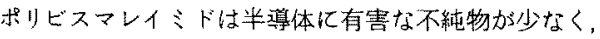
高集皘度LSI，高周波トランジスタ，ハイパワートラン ジスタなどの耐熱生封止樹脂として好適と言われる。

高純度ポリイミトを $\mathrm{Si}_{3} \mathrm{~N}_{4} や \mathrm{SiO}_{2}$ に代子て半導体のパ シベーションに利用するととも検討されている。酎熱性 の点からラダー型ポリイソインドロキナゾリンージオン (PIQ) 毛との目的に注目される。これらの雱熱性樹脂老 層間絶縁やパシベーション膜として半導体の一部に組入 れて利用すると多層絶縁が容易になり，菜子を外部応力 から保櫵するのに有効である。

\section{(5) 電子機器用絶縁部品}

電子機器用のコネクタ、スイッチ。コイルボビン，ブ ッシング、ソケット，コンデンサフィルムその他の絶彎 部品にはPS, PES, PPS, PEEK，Uポリマなどの 耐熱性熱可塑性樹脂の使用が自受けられる。いずれすガ ラス緎維で 20 名程度補強した材料が機械強度之耐熱性が 良好で実用価値が大きい。

てれらの樹脂の特徵上応用の二，三を述べると PSは 低周波加 $10^{6} \mathrm{~Hz}$ までの広い周波数領域で誘電特性がす 
ぐれて扔りコンピュータ部品，医療機器部品などで高周 波特性を要するすのに応用される。

PESはセラミック絶縁体に代ってサイリスタのシー 儿䋓縁に使用されている。射出成形による量産加可能で， 高温に扔りる耐曲げ性，耐クリープ性，耐化学薬品性， 耐トラッキング性も良く，水蒸気，油、溶剂，麼埃の侵 入防止に大さな効果を発揮する。また，180 $\mathrm{C}$ 程度まで 連続使用が可能で，ピンの自動播入に対応するため寸法 精度が要求される集皘回路用ソケットの製造に適する。

PEEKは成形品以外に季䩂熱性フレキシブル印刷回路 の基材，H種薄葉絶縁材料，榔熱性の電線，ケーブルの 押出し絶縁被覆，耐热，酎食性絶縁笁料など多方面への 応用が考えられている。

\section{7. 今後の動问}

耐熱性絶縁材料は現在各分野の機器に広く応用されて おり，今後む用途上使用量が漸堌する傾问にある。
これに対してその開発目標は現用の材料上り屯数段 すぐれた耐熱性を有する超酎熱性絶縁材料と使い勝手が 良く，比較的低コストの沉用耐熱性絶緣材料の二つに 䈯かれており，最近では後者住力されているようであ る。

作業性に富み，安洒なF種乃至 $\mathrm{H}$ 種絶縁用の耐熱性絶 縁材料の早急な出現が大いに期待される。

一力，罗来の超耐熱性䋓縁材料の主成分之なる新しい 酎熱性高分子の研究開発にも十分留意する必要肪ある。

てれによって，譏器の性能や信頼性浮飛躍的向上か あたらされると共に新製品開発に毛貢献することである う。

\section{参考文献}

電気・電子絶縁材料：電気絶縁材料工業会編

(昭和 58 年 5 月 13 日受理)

\section{関西支部公開講演会報告}

期 日：昭和 58 年 6 月 21 日 (火)

場 所：大阪化繊会館地下 6 号室

出席者：関西支部長はか 25 名

講 演：最近の欧州の合䋐事情と研究開発動问

演者：青 谷寞 東レ研究開発企画部 主席部員

要 旨:

演者の青谷 寛氏は東し欧州䮃在員として，ロンドン に約 5 年間駐在され最近㷌国された万で，欧州の合織会
社の最近の動问，特に不況対策や企業合併についてスラ イドを使い與味滐く説明された。また10年前之現在の研 究開発の対象の推移の説明があり，又 5 年後に欧州の合 䋘会社が市場に出をうとしているものについての説明が あった。プロ七スは紡績，染色仕上のし易い綿での笚純 化プロセス, 新品種では天然䋐維ライクの易染色でComfortが求められて求り，High Performance 織維とし ては無機結維の紹介肪あり，その外SNIA社のFiber S, ICI社のMitrelle, AKZO社のArenka, DSM 社の Nylon 46, Super High Tenacity P.E., ICI 社の PHBO紹介があった。（甲南女子大 渡辺正元記） 